\title{
Food Safety in China: Implicationsof Accession to the WTO
}

Denise Prévost

\section{(2) OpenEdition \\ 12 Journals}

Electronic version

URL: http://journals.openedition.org/chinaperspectives/5807

DOI: 10.4000/chinaperspectives.5807

ISSN: 1996-4617

\section{Publisher}

Centre d'étude français sur la Chine contemporaine

\section{Printed version}

Date of publication: 30 March 2012

Number of pages: $39-47$

ISSN: 2070-3449

\section{Electronic reference}

Denise Prévost, « Food Safety in China: Implicationsof Accession to the WTO », China Perspectives [Online], 2012/1 | 2012, Online since 30 March 2015, connection on 28 October 2019. URL : http:// journals.openedition.org/chinaperspectives/5807 ; DOI : 10.4000/chinaperspectives.5807 


\title{
Food Safety in China: Implications
}

of Accession to the WTO

\author{
DENISE PRÉVOST*
}

\begin{abstract}
The interaction between trade and health objectives has assumed critical importance for China since its accession to the World Trade Organization (WT0). The wish to improve its access to foreign markets has had a visible impact on China's food safety policy, providing significant impetus for far-reaching reforms. The WTO Agreement on Sanitary and Phytosanitary Measures (SPS Agreement), to which China is now bound as a WTO Member, sets out a "best practices" regulatory model with which national food safety regulation must comply. The disciplines it entails on regulatory autonomy in the area of food safety may present considerable challenges for China but have the potential to promote rationality in such regulation and to prevent food safety regulations that are based on unfounded fears or are a response to protectionist pressures from the domestic food industry. Faced with the possibility of challenges by other WT0 Members to its food safety measures on the grounds of non-compliance with WTO rules, China has a strong incentive to improve conformity with this regulatory model, bringing benefits not only to exporters but most importantly to its citizens.
\end{abstract}

KEYWORDS: Food safety, WTO, SPS Agreement, transparency, harmonisation, scientific assessment, regulatory autonomy.

T he accession of China to the World Trade Organization (WTO) has had a visible impact on its internal regulatory policy, nowhere more so than in the area of food safety. Not only has WTO membership provided a significant impetus for far-reaching reforms to China's food safety regime, but it has also supplied a "best practices" regulatory model with which these reforms must comply. This model is laid down in the WTO Agreement on Sanitary and Phytosanitary Measures (SPS Agreement).

This contribution aims to examine the effect of WTO accession on food safety in China, with a focus on the potential opportunities and challenges presented by the legal disciplines contained in the WTO's SPS Agreement. In view of growing recognition of the need to assess the "human dimension" of international trade rules, this evaluation of the impact of WTO law on the sensitive issue of food safety merits critical attention.

First, a brief description of food safety concerns related to Chinese products is given to set the context for the discussion. Thereafter, the reforms undertaken by China of its regulatory regime for food safety after its WTO accession are sketched out and the remaining problems highlighted. This review is followed by an examination of the trade implications of these reforms.

The analysis then turns to the SPS Agreement to determine whether it provides sufficient scope for China to pursue its food safety objectives, and where the limits to such regulatory autonomy are set. The objective is to identify the impact that these WTO rules have on China's new food safety regime, in order to establish whether they threaten the progress made by China towards stronger protection against food safety risks, or instead promote a better, more rigorous regulatory model for the promotion of food safety.

\section{Concerns regarding safety of Chinese food products}

The safety of food produced in China is currently of widespread concern. Weak and fragmented regulatory controls, (1) poor agricultural and veterinary practices, (2) small-scale, and thus difficult to control, production of food and agricultural products, (3) adulteration in food production

* Denise Prévost is Associate Professor of International Economic Law at Maastricht University, the Netherlands. She also regularly does consulting work for the European Commission, industry groups, national ministries, and law firms on WTO law matters. Denise frequently lectures at conferences and in capacity-building workshops on sanitary and phytosanitary issues and WTO dispute settlement. Until September 2011, she was Deputy Director of the Institute for Globalisation and International Regulation of Maastricht University.

1. In terms of the Chinese government's Decision on Further Strengthening Food Safety Supervision of 2004, responsibility for food safety is allocated to various Covernment bodies, including the Ministry of Agriculture (MOA), which has authority over the production of primary agricultural products; the State Administration for Quality Supervision, Inspection and Quarantine (AQSIQ), which supervises the quality and hygiene of food processing; the State Administration of Industry and Commerce (SAIC), which controls food circulation and distribution; and the Ministry of Health (MOH), which oversees the catering industry. This fragmented infrastructure for food safety is further complicated by the fact that the administrative structure in China involves 33 provinces, autonomous regions, or municipalities under the Central Covernment, 333 regions, municipalities, autonomous prefectures, and 2,861 counties and county-level municipalities. Most of these various levels of administration have food safety control authorities reporting to the SFDA, MOH, MOA, SAIC, and AQSIQ in their respective areas of competence. United Nations in China, "Occasional Paper - Advancing Food Safety in China," March 2008, p. 12, www.un.org.cn/public/ resource/2aebcd033e334d961fefb1588b70f2ab.pdf (consulted on 20 February 2012).

2. The heavy use of agricultural chemicals (e.g. pesticides and fertilisers) and veterinary drugs has been reported as a food safety concern. Banned chemicals are still available in China and sold illegally. F. Gale \& J.C Buzby, "Imports from China and food safety issues," Economic Information Bulletin, no. 52, July 2009, www.ers.usda.gov/publications/eib52/eib52.pdf (consulted on 20 February 2012).

3. As noted in a $2008 \mathrm{UN}$ paper, "The sheer scale of China's food industry makes the task of aligning all Chinese food products with international standards an ongoing and arduous one. Without considering food service establishments, there are currently around 450,000 different enterprises engaged in food production and processing in China. Of these, around 350,000 are small enterprises with less than ten employees which have a collective market share of less than ten per cent but present many of the greatest food safety challenges. In addition, there are many informal and unregistered producers whom it is even harder to oversee and regulate." United Nations in China, "Occasional Paper - Advancing Food Safety in China," op. cit., p. 6. 
processes, ${ }^{(4)}$ and widespread corruption have all contributed to undermining the safety level of food products. This situation has led to a number of food scares in recent years. Examples of these are rife, including the Greenpeace reports on excessive levels of poisonous pesticides on certain vegetables in April 2006; (5) the discovery in 2009 by Wuhan inspectors that blood pudding sold in Chinese markets was composed mainly of corn starch, formaldehyde, industrial grade salt, and food colouring; ${ }^{(6)}$ and findings by Chinese officials of illegal drugs in fish farming in December 2006. (7) Other reported examples include Longkou noodles containing lead from Shandong, fake alcohol in Guangdong, and soy sauce made from human hair. ${ }^{(8)}$

With China's accession to the World Trade Organization (WTO) in December 2001, these food-safety concerns have come to the forefront of public and media attention. The lowering of trade barriers to Chinese products following its WTO accession, as mandated by the WTO agreements, has meant that Chinese food exports have increased access to foreign markets, ${ }^{(9)}$ raising fears of the spread of food safety risks to importing countries. ${ }^{(10)}$ In 2008, for instance, dumplings produced in China caused more than 700 people to fall ill in Japan. ${ }^{(11)}$ The most infamous example is that of the infant milk scandal in 2008, where "trusted" (and thus largely unsupervised) ${ }^{(12)}$ Chinese producers of milk products, primarily the Sanlu company, were found to have adulterated the products with melamine. (13) Melamine is an industrial chemical used to falsely inflate the apparent protein content of products. As Chinese producers had developed the practice of watering down their milk, melamine could be used to boost the apparent protein content to the levels required by regulation. However, the ingestion of the chemical by infants in milk formula led to kidney damage, with six deaths and approximately 294,000 cases of illness, of which 51,900 required hospitalisation. ${ }^{(14)}$ Despite many previous complaints from Chinese citizens regarding infant illness following Sanlu milk ingestion, nothing was done until the problem "erupted on the international scene." (15) Melamine-contaminated products spread rapidly and were soon found in 46 other countries. (16) In response to the infant milk scandal, a number of countries banned all dairy imports from China or tightened their sanitary controls on imports of Chinese dairy products. Investigations into contamination of milk with melamine soon revealed that the problem was more widespread than previously imagined, with excessive melamine levels found in soya milk, yoghurt ice-cream, Mailai (a dessert), poultry feed, eggs, and fish food. (17) Another such instance of melamine contamination had already occurred in 2007, in pet food produced with vegetable proteins imported from China. It resulted in largescale kidney failure and death of pets in the North America, Europe, and Australia. Leading pet food companies, such as Nestle Purina PetCare, Royal Canin, and Menu Foods that used protein ingredients produced in China were affected and had to initiate worldwide product recalls. ${ }^{(18)}$

These and other scares regarding the safety of food and feed exports from China have led other WTO Members to take a particularly cautious approach to these Chinese products, imposing strict food safety controls, which result in market access restrictions and a reduction in export revenue for China. ${ }^{(19)}$ European and Japanese bans on shrimp, honey, and other food products from China have "reinforced the impression that both consumers and policy makers are ready to act on safety concerns." (20) The food industry in China has therefore faced rising demands to meet the food safety standards required on its more lucrative export markets, such as those of the US, EU, and Japan, or be denied entry to those markets.

The issue of food safety is, however, not only of growing importance for China's export earnings from food trade. There is also emerging demand among Chinese consumers for safer food, and a willingness to voice their concerns in this area. It has been argued that the Melamine scandal provided Chinese citizens with "an opportunity to voice their legitimate concerns, usually forbidden in the strictly political field." (21) As urban incomes rise, and primary health issues such as basic sanitation and hygiene become less pressing, consumers show greater consciousness of health risks from food. Currently, food poisoning and food-borne disease remain serious health threats in China. ${ }^{(22)}$ In addition, with growing urban affluence comes increased consumer demand for processed and pre-packaged foods, which

4. According to The New York Times, food safety scandals in China "are proliferating, in part, because producers operate in a cutthroat environment in which illegal additives are everywhere and costeffective. Manufacturers calculate correctly that the odds of profiting from unsafe practices far exceed the odds of getting caught, experts say." "In China, Fear of Fake Eggs and 'Recycled' Buns," The New York Times, 7 May 2011. A similar finding was reported in a United States Department of Agriculture (USDA) publication, which states: "Some producers and merchants in China's highly competitive market cut corners, add toxic substances, or skimp on food safety controls to fatten razor-thin profit margins or gain some other competitive edge." F. Gale \& J.C Buzby, "Imports from China and food safety issues," op. cit.

5. It is reported that, "From December 2008 to February 2009, Greenpeace bought 15 commonlyeaten fruit and vegetable samples from agricultural markets and the supermarkets Wal-Mart, Vanguard, Lotus, and Nonggongshang, in Beijing, Shanghai, and Guangzhou respectively, and sent all 45 samples of fruits and vegetables to an independent laboratory in Qingdao for testing. The results show that only five samples out of the total 45 contained no pesticides and over 50 different kinds of pesticides were identified on the rest." See "Greenpeace Finds Pesticide Residues In Chinese Fruit And Veg," China CSR, 27 April 2009; Patton, Dominique "Pesticide residues still high in Chinese vegetables" AP-FoodTechnology.com, 25 April 2006.

6. "Wealthy Chinese Are Pursuing Their Own Food Safety," The Epoch Times, 23 December 2010.

7. "Carcinogenic Turbot Fish Affects China's Market," The Epoch Times, 2 December 2006; "Shandong Turbot farmers in crisis following sales slump," The Fish Site, 22 December 2006.

8. King \& Wood PRC Lawyers, "PRC Food Safety Law: Food for Thought," China Law Insight, 27 March 2007.

9. According to a $2008 \mathrm{UN}$ paper, China's food exports have been increasing at a rate of more than 20 percent year-on-year to reach US\$27 billion in 2006. United Nations in China, "Occasional Paper - Advancing Food Safety in China," op. cit., p. 18. From the date of its accession until 2008, China's food exports to the US tripled in value, making China one of the fastest growing sources of food imports to the US. F. Gale \& J.C. Buzby, "Imports from China and food safety issues," op. cit.

10. In the United States, a 2007 Gallup/USA Today poll found that 46 percent of those polled were "very concerned" and another 28 percent were "somewhat concerned" about the safety of Chinese food exports. Jennifer Pifer, "Avoiding Chinese food products nearly impossible," CNN, 26 July 2007.

11. Ching-Fu Lin, "Global Food Safety: Exploring key elements in an international regulatory strategy," Virginia Journal of International Law, vol. 51, no. 3, 2011, pp. 637-696.

12. Under the Chinese system of "trusted" companies, certain reputable companies are exempted from the generally applicable controls and are thus left largely unsupervised. Sanlu, the main culprit in the melamine scandal, was one of these trusted companies.

13. This was done in order to meet the government's minimum protein content requirement for raw milk, which reportedly does not reflect the reality of China's dairy industry. The secretary general of the Heilongjiang Dairy Industry Association noted that between 75 percent and 90 percent of raw milk in some provinces failed to meet the required protein level in 2007 and 2008.

14. "Ministry: Six infants possibly died of tainted milk powder," Window of China, 1 December 2008.

15. Frederic Keck, "The contaminated milk affair," China Perspectives, no. 2009/1, p. 88.

16. Ching-Fu Lin, "Global Food Safety: Exploring key elements in an international regulatory strategy," op. cit., p. 646.

17. Ibid., p. 90.

18. Julie Schmit, "Premium pet food company recalls dry foods," USA Today, 17 April 2007; "Menu Foods Recall Frequently asked Questions," American Veterinary Medical Association, 2 April 2007; "104 Deaths Reported in Pet Food Recall," The New York Times, 28 March 2007.

19. The UN reports that food safety concerns by importers and foreign consumers may threaten the growth in China's food exports United Nations in China, "Occasional Paper - Advancing Food Safety in China," op. cit., p. 18.

20. United Nations in China, "Occasional Paper - Advancing Food Safety in China," op. cit., p. 18. This paper further notes that "[i]n 2006 and the first half of 2007 , the USA found that 0.8 and $0.9 \%$, respectively, of imported Chinese foodstuffs were substandard. For the EU, the corresponding figures were $0.1 \%$ and $0.2 \%$, respectively. For Japan, the figure for 2006 was $0.58 \%$."

21. Frederic Keck, "The contaminated milk affair," op. cit., p. 88.

22. Roger Skinner, "Regulatory and Strategic Framework for Food Safety in the People's Republic of China," SFDA, ADB, WHO Cooperation Project, 25 June 2007, www.adb.org/Documents/ProducedUnder-TA/37599/Food-Safety-FS-EN.pdf (consulted on 23 February 2012). 
are more susceptible to contamination by pathogens. In addition, a growing Chinese agro-industry using new technologies, including chemical fertilisers and pesticides, genetic modification, irradiation, and veterinary drugs, poses new challenges for food safety controls. ${ }^{(23)} \mathrm{A}$ recent study has shown that urban consumers in China are increasingly aware of food safety issues, and are willing to pay a price premium for safe food. (24) This development creates an economic incentive for the Chinese food industry to address food safety issues, aside from that arising from the need for access to foreign markets.

However, industry initiatives alone cannot be relied upon to ensure high levels of food safety; governmental support is needed in the form of adequate regulations; infrastructure to carry out the necessary inspections, testing, and certification; and enforcement mechanisms to ensure compliance. Due to the fact that food safety risks are often not publicly visible or ascertainable, consumers have to rely on the good practices of food producers and retailers and the careful oversight of the government to ensure safe food. To build the trust of consumers and foreign importers in the safety of Chinese food products, a food safety regime that is reliable, science-based, and rigorously applied is essential. As noted by Stearns, referring to the significant level of trust needed for food exchanges, and the importance of regulation in building such trust: "There are few things that make one more vulnerable than eating. Accordingly (cr)edibility is the sine qua non of food exchange." (25) Clearly, without considerable regulatory reforms in the food production and distribution sectors, efforts to address the food safety problems in China cannot bear fruit.

\section{Post-accession reforms in China's food safety regime}

Efforts have been made to update and strengthen food safety controls in China in response to demands from China's export markets and also domestic consumer concerns. In 2003, less than two years after China's WTO Accession, efforts were made by the Chinese government to consolidate food safety regulation by establishing the State Food and Drug Administration (SFDA) of China, a central coordinating agency for food safety issues. While this has facilitated addressing the problem of fragmentation of control, the SFDA has reportedly "not yet been given sufficient staff or the resources to fully implement its mandate. There remains a situation where a relatively large number of agencies are involved in the area of food safety with overlapping responsibilities but without any practical and effective means of coordinating the development of policy or its implementation." (26)

China's Eleventh Five-Year Plan (2006-2010) set improving food safety as "a critical national task, as part of realizing a vision of human-centred, science-based development." (27) However, many problems remained, leading the Asian Development Bank (ADB) to issue a report based on a World Health Organization project in early 2007, (28) which pointed to remaining gaps in China's food safety regime and recommended urgent reforms to strengthen and streamline coordination between different agencies involved in food safety regulation. The primary legislation on food and feed safety protection in China is composed of the Law on Quality and Safety of Agricultural Products, the Law on the Entry and Exit of Animals and Plant Quarantine, the Food Hygiene Law, the Law on Animal Disease Prevention, the Law on Import and Export Commodity Inspection, and the Law on Frontier Health and Quarantine, together with the implementing regulations and rules. ${ }^{(29)}$ The ADB report called for enactment of an overarching "basic food law," which would cover all stages of food production and set out general principles of food law. ${ }^{(30)}$ It further noted the need to bring food safety requirements in line with accepted international standards.

Additional impetus for increased efforts to bring about reform in China's food safety regime was generated by the 2008 melamine infant formula scandal mentioned above. (31) Subsequently, on 28 February 2009, the new PRC Food Safety Law was approved by the National People's Congress, and entered into force on 1 June 2009. (32) This law provides a legal basis for the government to strengthen food safety control "from farm to fork." It sets out requirements for risk assessments and scientific methods in food safety regulation. It further consolidates hundreds of regulations and standards and sets out stricter penalties for producers of unsafe food products. ${ }^{(33)}$ In addition, it creates a unified standard-setting procedure, an enhanced monitoring and supervision system, a product-recall system, and a set of national safety standards. ${ }^{(34)}$ It also abolishes the system of exemptions for "trusted" companies, in direct response to the melamine infant milk scandal. Also, the law addresses most particularly the issue of food additives, which was central to the melamine scandal. Under the new law, additives are prohibited unless proven to be not only safe but also necessary. ${ }^{(35)}$

As mandated by the new Food Safety Law, February 2010 brought the establishment of a food safety commission consisting of three vice premiers and 12 ministerial-level officials. The Commission aims to address the problems with China's food regulatory regime by improving government coordination and enforcement, and solving systemic food safety problems. The head of the national food safety commission, Vice Premier Li Keqiang, stated before the State Council in Beijing in 2010, "Food is essential, and safety should be a top priority. Food safety is closely related to people's lives and health and economic development and social harmony." (36)

23. Ibid.

24. Zhigang Wang, Yanna Mao, Fred Gale, "Chinese consumer demand for food safety attributes in milk products," Food Policy, vol. 33, no. 1, February 2008, pp. 27-36. This study found that almost all Chinese urban consumers who were made aware of the risk management strategy in milk production of Hazard Analysis and Critical Control Point (HACCP) were willing to pay a premium of about 5 percent for HACCP-certified milk products.

25. Denis Stearns, "On (cr)edibility: Why food in the United States may never be safe," Stanford Law and Policy Review, vol. 21, no. 2, 2010. See also Denis Stearns, "Of recycled buns, China and the Jabberwocky," Food Safety News, 11 May 2011.

26. United Nations in China, "Occasional Paper - Advancing Food Safety in China," op. cit., p. 13.

27. Ibid., p. 4.

28. This report was based on a technical assistance project carried out in collaboration with China's State Food and Drug Administration and the World Health Organization. Roger Skinner, "Regulatory and Strategic Framework for Food Safety in the People's Republic of China," SFDA, ADB, WHO Cooperation Project, op. cit.

29. Trade Policy Review Body, Trade Policy Review - China: Report by the Secretariat, Revision, WT/TPR/S/230/Rev.1, 5 July 2010, Part III.

30. Roger Skinner, "Regulatory and Strategic Framework for Food Safety in the People's Republic of China," SFDA, ADB, WHO Cooperation Project, op. cit.

31. For a useful analysis of the effect of the melamine infant formula scandal on food safety regulation in China, see Xiaofang Pei, Annuradha Tandon, Anton Alldrick \& Liana Giorgi, "The China melamine milk scandal and its implications for food safety regulation," Food Policy, vol. 36, no. 3, 2001, Pp. $412-420$

32. The Food Safety Law of the People's Republic of China, promulgated by the Standing Committee of the National People's Congress on 28 February 2009, in force on 1 June 2009, www.procedurallaw.cn/english/law/200903/t20090320_196425.html (consulted on 22 February 2012).

33. Firms that produce or sell sub-standard food may be fined up to ten times the product price, in addition to being required to compensate for the harm caused by the product to consumers. In severe cases criminal prosecution is also foreseen. King \& Wood PRC Lawyers, "PRC Food Safety Law: Food for Thought," op. cit.

34. Ibid.

35. Ibid.

36. "Chinese Vice-Premier orders more efforts to improve food safety," Xinhua, 20 April 2010. 


\section{Trade implications of China's food-safety regime}

The new initiatives to address food safety issues in China have important trade implications on two fronts. On one side, as discussed above, they may go some way toward alleviating food safety concerns associated with Chinese food exports and thus increase market access for these products. The flip side of this issue is that the new regulations and procedures that comprise the current Chinese food safety regime may create considerable barriers to the Chinese market for foreign products.

Regulations that aim to protect the health of humans or animals against food- or feed-borne risks, commonly known as sanitary measures, may lay down requirements for food or agricultural products (such as requirements regarding permissible additives in processed foods) or for the production processes by which these food products are made (such as hygiene requirements for abattoirs). Examples of sanitary restrictions to access to the Chinese market are its "zero-tolerance" limit for the Salmonella bacterium in imported poultry meat; (37) its bans on animal products in response to outbreaks of Bovine Spongiform Encephalopathy (BSE or "mad cow disease") and H1N1 influenza (swine flu); and its maximum residue levels (MRLs) for certain heavy metals and veterinary drugs. ${ }^{(38)}$ All these measures have been the subject of concern by China's trading partners, which view them as unjustifiably trade restrictive.

Sanitary measures are usually accompanied by rules regarding conformity assessment procedures, which are control mechanisms to check compliance with the relevant safety requirements. These may take various forms, such as certification systems, random sampling and testing procedures, systems for prior approval of additives, and pre-shipment inspections. They may be imposed on products within the domestic market, for example requirements regarding veterinary inspections of cattle within the national territory, or on products crossing borders, either at the time of importation or exportation. (39) Examples of conformity assessment requirements in China are those of entry/exit inspection on sanitary grounds, which is required for products listed in China's Catalogue of Entry-Exit Commodities Subject to Inspection and Quarantine, ${ }^{(40)}$ and of certifying the disease-free status of imported dairy products. ${ }^{(41)} \mathrm{A}$ controversial example is China's requirement of additional testing and inspection for H1N1 on pork products exported to China as well as disinfection of containers, which has been questioned as disproportionate and lacking in scientific justification. ${ }^{(42)}$

The potential restrictive effect of such sanitary measures and their conformity assessment procedures on market access for imported food products is clear. It is therefore interesting to examine the rules of the World Trade Organization (WTO) that discipline the trade restrictive effect of such health regulations and the accompanying conformity assessment procedures. These disciplines are contained primarily in the Agreement on Sanitary and Phytosanitary Measures (SPS Agreement). ${ }^{(43)}$ This agreement aims to balance the need to further the liberalisation of trade in food and agricultural products on the one hand, with the acknowledged sovereign right of WTO Members to address the health risks arising from food or feed and from pests and diseases of plants and animals on the other. ${ }^{(44)}$

The SPS Agreement will therefore be examined to establish the extent to which it provides scope for China to pursue its food safety objectives, and where the limits to such regulatory autonomy are set. This will also determine the possibilities for otherWTO Members to pursue their trade interests by using the rules of the SPS Agreement to challenge China's sanitary meas- ures. Before doing so, however, it is essential to understand the principle objective of the SPS Agreement as a tool to balance the competing interests of trade liberalisation and health protection. This matter will be addressed first in order to provide the context within which the following discussion should be understood.

\section{Balancing role of the SPS Agreement}

Both trade liberalisation and health protection measures pursue important societal objectives, namely economic growth and development through the earning of foreign revenue, and the protection of the life and health of humans, animals, and plants. However, these two objectives are often in conflict with one another.

On the one hand, as seen above, traded products, particularly in the food and agricultural sector, can introduce risks to health in the importing region, such as the transfer of infectious diseases carried by imported animals or animal products (such as Creutzfeldt-Jakob Disease), and food safety risks from inadequate standards in the production, processing, or transportation of food imports. These risks are ever-increasing due to the changing nature of traded agri-food products. There is a growing demand for processed food products, and thus more possibilities for contamination at various stages of the processing chain. Risks are compounded by the use of new technologies in agriculture and food processing, such as pesticides, additives, irradiation, and genetic modification. Further, there is growing trade in fresh and perishable products, which are more vulnerable to infection by pests and pathogens than traditionally traded bulk agricultural commodities such as dried grains and pulses. States thus need to take protective measures to respond to citizens' demands for food safety.

On the other hand, the sanitary measures that importing states take in their territories to protect health from such risks are likely to act as significant barriers to market access for the exporting country, thereby reducing its export earnings and affecting rural livelihoods. Food safety requirements

37. United States Trade Representative, 2010 Report to Congress on China's WTO Compliance, December 2010, p 79.

38. Ibid., p. 80.

39. One example of conformity assessment at the time of exportation is the importing company's requirement of export certificates. Horton notes that export certificates serve to show that a supplier meets certain requirements and are based on the expectation that the certifying body (either a government authority or officially recognised non-governmental organisation) will conduct inspections or tests to substantiate the accuracy of the information on the certificate. Linda R. Horton, "Food from Developing Countries: Steps to Improve Compliance," Food and Drug Law Journal, vol. 53, no. 1, 1998, pp. 139, 147

40. Trade Policy Review Body, Trade Policy Review - China: Report by the Secretariat, Revision, WT/TPR/S/230/Rev.1, 5 July 2010, Part III, para 51.

41. United States Trade Representative, 2010 Report to Congress on China's WTO Compliance, op. cit., p. 81.

42. Committee on Sanitary and Phytosanitary Measures, Transitional Review Mechanism Pursuant to Paragraph 18 of the Protocol on The Accession of the People's Republic of China ("China"), Questions from the European Communities to China concerning Sanitary and Phytosanitary Measures, G/SPS/GEN/968, 20 October 2009, para 7.

43. It is perhaps useful to note that the SPS Agreement covers not only sanitary measures (which aim to protect human or animal health) but also phytosanitary measures (which aim to protect plant health). Since this contribution addresses food and feed safety issues, it will not examine the latter category of measures. Suffice it to say that they are covered by the same disciplines in the SPS Agreement as those discussed here.

44. It should be noted that while the WTO may lay down a best practices model for food safety regulation in the SPS Agreement, it has no competence to carry out regulatory activities itself. As such, it cannot lay down minimum food safety standards with which its members must comply. By contrast, the World Health Organization (WHO) has normative powers and the mandate to address global health issues. For a critical look at the failure by the WHO to make full and effective use of its authority to lay down food safety norms, see Ching-Fu Lin, "Global Food Safety: Exploring key elements in an international regulatory strategy," op. cit., pp. 673-684. 
thus have an important impact on exports in the agricultural sector (both primary and processed products). In addition, these requirements could be misused for protectionist purposes, thereby undermining the gradual gains in the liberalisation of agricultural trade pursued under the WTO's Agreement on Agriculture. ${ }^{(45)}$ It is notable that regulators are faced with pressure from domestic agriculture and food industry lobbies in the face of increased competition due to progress in agricultural liberalisation. The first hard-won steps towards liberalising this traditionally protected sector and the subsequent ongoing agricultural trade liberalisation mandated by the Agreement on Agriculture, (46) the subject of torturous and now stalled negotiations in the context of the Doha Round of trade negotiations, ${ }^{(47)}$ aim to break down the traditional protection (tariffs, export subsidies, and domestic support) that shields domestic producers from competition. The agricultural industry therefore lobbies regulators to erect non-tariff barriers to trade in the form of sanitary (human and animal health) or phytosanitary (plant health) regulations.

While the potential conflict between sanitary and phytosanitary measures and trade is not a new phenomenon, the exponential increase in the speed and diversity of traded agri-food products in the last 50 years, and the accompanying proliferation of health risks and of measures to address them, has meant that the international trade regime embodied in the rules of the WTO has had to find new ways of mediating this conflict. The SPS Agreement reflects a negotiated balance between the competing goals of the liberalisation of agri-food trade and the protection of health by national governments. In examining the rules of the SPS Agreement and their implications for China's food safety regime, this balancing objective must be kept in mind.

\section{Disciplines on China's food safety measures under the SPS Agreement}

In acceding to the WTO in December 2001 China was bound to all WTO obligations to promote the elimination or reduction of trade barriers, including those contained in the SPS Agreement. ${ }^{(48)}$ Beijing has made significant progress in reforming its trade policy to comply with its WTO obligations. Nevertheless, several barriers to trade remain in the form of food safety measures, as can be seen by the concerns raised by WTO Members during recent reviews of China's trade policies, ${ }^{(49)}$ and by EU commercial operators in the Chinese market. ${ }^{(50)}$ It is useful to assess these food safety barriers in terms of the obligations laid down by the SPS Agreement. This section will therefore focus on those disciplines of the SPS Agreement of relevance to the aspects of China's food safety regime that lead to trade concerns raised by other WTO Members. It will be seen what impact these WTO rules have on China's new food safety regime, in order to establish whether they threaten the progress made by China towards stronger protection against food safety risks, or instead promote a better, more rigorous regulatory model for the promotion of food safety.

\section{Harmonisation}

The sovereign right of national governments to pursue the legitimate societal aim of the protection of health against food safety risks is recognised by the SPS Agreement. While it requires that such measures be sciencebased, non-discriminatory, and applied only to the extent necessary to protect health, the SPS Agreement leaves much room for members to make policy choices regarding the level of health protection they wish to ensure in their territories. These choices reflect particular conditions in each member, including consumer preferences, economic considerations, and industry interests. The specific food safety requirements that WTO Members may impose to achieve their chosen level of health protection therefore also diverge. Differences in food safety requirements can nevertheless act as significant trade barriers as exporters are forced to adjust their products or production processes to the different standards of their various export markets, thereby reducing economies of scale. The promotion of harmonisation of food safety regulations at the international level has emerged as a response to this problem. If all countries are encouraged to adopt food safety requirements that are developed internationally, the divergence in requirements imposed on exporters decreases, as do the costs of adapting to regulatory requirements on export markets. As the WTO is not a regulatory body with norm-setting capacity in the area of health, it cannot set the international standards to be used as benchmarks. The SPS Agreement therefore encourages WTO Members to harmonise their food safety requirements around the standards developed by existing authoritative international bodies. ${ }^{(51)}$ In the area of food safety this is the Codex Alimentarius Commission (CAC), and in the area of diseases carried by animals, including those that can be transferred to humans (zoonoses), this is the World Animal Health Organisation (OIE). (52) Food safety measures that conform to these international standards are granted a safe harbour from challenge by other members by means of a presumption of consistency with all the obligations of the SPS Agreement. ${ }^{(53)}$ If Members choose to apply measures reflecting a higher level of protection than those embodied in existing international standards, scientific justification is required in the form of a risk assessment. ${ }^{(54)}$

45. The Agreement on Agriculture is among the agreements resulting from the Uruguay Round of trade negotiations. It takes the first steps towards liberalising the agricultural sector, which is traditionally among the most protected sectors in international trade. The Agreement on Agriculture imposes disciplines on traditional barriers to trade in this sector, namely tariffs, domestic support, and export subsidies. These disciplines could be undermined if complementary rules were not in place to prevent the use of regulatory requirements for disguised protectionist purposes. See "Agreement on Agriculture," in The Results of the Uruguay Round of Multilateral Trade Negotiations: The Legal Texts, World Trade Organization, 1994, pp. 39-68

46. Ibid., Art. 20.

47. Ministerial Conference, Doha Ministerial Declaration. Adopted on 14 November 2001, WT/MIN(01)/DEC/1, circulated on 20 November 2001, paras 13-14. The work programme set out in the Ministerial Declaration with regard to agriculture aims at substantial improvements in market access; a gradual phasing out of export subsidies; and substantial reductions in trade-distorting domestic support.

48. China's WTO obligations are those contained in the WTO Agreement, including all of its Annexes, as well as the Protocol of Accession of China to the WTO (WT/L/432), and the incorporated paragraphs of its Working Party Report (WT/ACC/CHN/49).

49. The WTO administers a Trade Policy Review Mechanism, which conducts periodic reviews of the trade policies of all Members, in the context of which the WTO Secretariat and the reviewed Member submit reports that are discussed in a meeting of the Trade Policy Review Body. Other Members may submit questions and concerns, and the reviewed Member may respond. The latest Trade Policy Review of China was conducted in 2010, and the reports are to be found in WTO documents WT/TPR/S/230/Rev. 1 and WT/TPR/G/230. In addition, Section 18 of the Protocol of Accession of China establishes the Transitional Review Mechanism for China. It provides for eight years of annual reviews of China's trade policies, concluding with a final review in the tenth year. The reviews are conducted by the 16 subsidiary bodies of the WTO with a mandate in the specific area of China's WTO commitments. These bodies report to the relevant WTO specialised council, which in turn reports to the General Council at the end of the year. The final review took place in October 2011.

50. The recent report of the EU Chamber of Commerce in China reflects these concerns. See European Union Chamber of Commerce in China, European Business in China Position Paper 2010/11, p. 167.

51. World Trade Organization, SPS Agreement, Article 3. www.wto.org/english/tratop_e/sps_e/spsagr_e.htm (consulted on 22 February 2012).

52. Ibid., Annex A.3, (a) to (e).

53. Ibid., Article 3.2 .

54. Ibid., Article 3.3 and 5.1. 
In recognition of the importance of international standards for its food trade, both as importer and exporter, China has been a member of the CAC since 1984 and has increased its active participation over the years. It has established a committee comprised of relevant ministries and commissions to deal with international standard-setting at the CAC. In 2006 China began hosting two important CAC Committees, namely the Codex Committee on Food Additives and the Codex Committee on Pesticide Residues. However, other WTO Members have frequently raised the complaint that China's food safety requirements are not based on international standards.

Inter alia, the European Commission (EC) has pointed out that China's SPS measures to address risks from H1N1 (swine flu) and Bovine Spongiform Encephalitis (BSE or mad cow disease) do not conform to the standards set by the relevant international bodies. ${ }^{(55)}$ For example, the OIE has listed which bovine products can be safely traded regardless of the BSE status of the exporting country, including de-boned skeletal muscle meat from cattle. The OIE has also classified 25 EU Member States as "controlled risk" or "negligible risk." Despite this, China continues to ban beef and other bovine products from the EU. Similarly, China continues imposing additional trade requirements on live pigs from EU Member States in response to the H1N1 influenza pandemic, demanding disease-free areas for live pigs exported to China. However, China has failed to provide adequate scientific justification for these stricter measures in either case. Lack of such justification constitutes a violation of the SPS Agreement.

In the same vein, the EU Chamber of Commerce has noted that with respect to food additives, China's Hygiene Standards for Uses of Food Additives include fewer than half of the additives approved for food use by the Codex Alimentarius Commission, indicating that the Chinese legislation lags behind the development of international standards. ${ }^{(56)}$ This results in unjustified barriers to exports from other WTO Members, and is thus vulnerable to challenge at the WTO. ${ }^{(57)}$

The promotion of harmonised food safety requirements by the SPS Agreement can be expected to provide an incentive for China to ensure that internationally recognised, science-based standards are generally used as the basis for its food safety regulations, except where it can scientifically justify a different choice. In harmonising its regulations, China would be able to shield them from challenge by other Members. For this discipline to be truly beneficial for China, however, it is important that China remain an active participant in the international standard-setting process in order to have a voice in the development of standards that will be the basis for its harmonisation efforts.

\section{Scientific justification}

Science is an essential tool used by the SPS Agreement to distinguish between measures aimed at health protection and those that are disguised forms of trade protectionism. The centrality of science to the operation of the SPS Agreement is thus irrefutable - it is the scale on which the competing values of health protection and trade liberalisation are balanced. The obligation of the SPS Agreement for a scientific basis to sanitary and phytosanitary measures can be seen as an attempt to ensure rational, sciencebased decision-making in national health regulation, and thereby to prevent private-interest hijacking of the regulatory process. ${ }^{(58)}$ In particular, in situations where harmonisation is not possible due to the lack of a relevant international standard, or is not feasible due to differences in national conditions or policy preferences, science operates to generate rational regulatory choices. ${ }^{(59)}$
To give effect to this objective, the SPS Agreement requires that SPS measures be based on scientific principles and not be maintained without sufficient scientific evidence ${ }^{(60)}$ (except in the case of provisional measures taken in situations of insufficiency of science, often called precautionary measures). ${ }^{(61)}$ This obligation is further fleshed out through the requirements that SPS measures be "based on" a risk assessment appropriate to the circumstances. ${ }^{(62)}$

Giving effect to these obligations, China's new Food Safety Law provides for a food safety risk assessment system to assess risks relating to biological, chemical, and physical hazards in food and food additives. The findings of food safety risk assessments not only lead to new regulations, but will also be incorporated into revisions to food safety requirements.

However, areas still remain where scientific assessments of risk do not form the basis for China's food safety measures. In these instances, the scientific disciplines of the SPS Agreement facilitate the efforts of exporting countries to regain market access that has been denied without wellfounded scientific reason. For example, in 2007 the EU was able to rely on the requirement of scientific justification in the SPS Agreement to challenge China's import restrictions on animal products due to alleged dioxin contamination. ${ }^{(63)}$ These restrictions were imposed after an isolated incident in January 2006, after which all possibly affected products were promptly recalled. Although all other WTO Members withdrew their trade restrictions, China maintained its ban. The EU raised its concerns before the SPS Committee and requested that China remove the ban or provide a scientific justification for its maintenance. Technical consultations between the EU and China followed and resulted in removal of the ban in October 2007.

A current example of a Chinese SPS measure that appears to lack a scientific basis is the limitation on the level of yeast in cheese to a maximum of $50 \mathrm{cfu} / \mathrm{g}$. In other markets where cheese consumption has a longer history, it is recognised that yeast in cheese poses no safety concern and no maximum limit is needed. ${ }^{(64)}$ The measure would thus appear not to be based

55. Committee on Sanitary and Phytosanitary Measures, Transitional Review Mechanism Pursuant to Paragraph 18 of the Protocol on The Accession of the People's Republic of China ("China"), Questions from the European Communities to China concerning Sanitary and Phytosanitary Measures, G/SPS/W/262, 6 October 2011, paras 11 and 15.

56. European Union Chamber of Commerce in China, European Business in China Position Paper 2010/11, op. cit., p. 168.

57. This issue was also raised by the EU in the context of the TRM. See Committee on Sanitary and Phytosanitary Measures, Transitional Review Mechanism Pursuant to Paragraph 18 of the Protocol on The Accession of the People's Republic of China ("China"), Questions from the European Communities to China concerning Sanitary and Phytosanitary Measures, G/SPS/W/262, 6 October 2011, para 9 .

58. Robert Howse, "Democracy, Science, and Free Trade: Risk Regulation on Trial at the World Trade Organization", Michigan Law Review, vol. 98, no. 7, June 2000 p. 2329.

59. As noted by Jacqueline Peel, "The very fact of having to take a risk assessment into account and respond to its findings could have the salutary effect of forcing national regulators 'to articulate objectives, to assess means, and to rationalize results,' a substantial improvement for the regulatory processes of many nations." See Jacqueline Peel, "Risk Regulation under the WTO SPS Agreement: Science as an International Normative Yardstick?," Jean Monnet Working Paper 02/04, NYU School of Law, New York, June 2004, p. 57, www.jeanmonnetprogram.org/papers/04/040201.pdf (consulted on 22 February 2012). The citation referred to by Peel comes from Henrik Horn and Joseph H.H. Weiler, "European Communities - Trade Description of Sardines: Textualism and Its Discontent," The WTO case law of 2002: The American Law Institute reporter's studies, pp. 248275.

60. Article 2.2 of the SPS Agreement.

61. As provided for in World Trade Organisation, SPS Agreement, op. cit., Article 5.7.

62. Ibid., Article 5.1. What is meant by a risk assessment is set out in Annex A.4 of the SPS Agreement.

63. Information regarding this issue is provided in Committee on Sanitary and Phytosanitary Measures, Specific Trade Concerns - Note by the Secretariat, G/SPS/GEN/204/Rev.8/Add.3, 1 March 2011, item 246.

64. European Union Chamber of Commerce in China, European Business in China Position Paper 2010/11, op. cit., p. 170. 
on a risk assessment, as required by the SPS Agreement. A cheese exporting WTO Member could therefore rely on the scientific disciplines of the SPS Agreement to raise its concerns regarding this trade restriction.

One can expect that the requirement of a scientific basis for SPS measures in the SPS Agreement will operate to ensure that China "objectively" demonstrates the necessity of its non-harmonised food safety regulations by reliance on risk assessments, thus avoiding the risk that regulations are adopted in response to domestic industry protectionist pressures. This can only benefit the food safety regime as a whole, while guarding against the welfare-decreasing hijacking of the regulatory process by industry interest groups. Nevertheless, the level of scientific capacity that this requirement entails is considerable. In this area, China may benefit from technical assistance by its trading partners or international initiatives such as the Standards and Trade Development Facility. ${ }^{(65)}$

\section{Undue trade restrictiveness}

While the SPS Agreement defers to the right of WTO Members to choose the level of SPS protection they deem appropriate for their territories, ${ }^{(66)}$ it disciplines the choice of an SPS measure to achieve this level of protection. In particular, members are obliged to ensure that their SPS measures are not more trade restrictive than required to achieve their appropriate level of SPS protection, taking into account technical and economic feasibility. ${ }^{(67)}$ Several instances have been noted where the conformity of China's food safety regime with this obligation is at issue.

For example, the EU has raised doubts as to the compatibility of the chapters on imports and exports in China's new Food Safety Law with the requirement of least-trade-restrictiveness. The $\mathrm{EC}$ noted the vagueness of how different procedures will work in practice, and was concerned that these may delay the processing of imports or cause trade disruptions. ${ }^{(68)}$ If alternative, less trade-restrictive measures can achieve the requisite level of protection from food safety risks, then the relevant chapters would be in violation of the SPS Agreement.

One of the most important trade restrictive measures facing agri-food exporters to China is the requirement of a Quarantine Inspection Permit (QIP) before a contract may be signed for these exports to be purchased. (69) China's State Administration of Quality Supervision, Inspection and Quarantine (SAQSIQ) has discretion to annul QIPs without prior notification or explanation, creating unpredictability for exporters. Further, delays in granting QIPs have led to shipments of agricultural products arriving in Chinese ports of entry without QIPs, resulting in delays to product discharge and unnecessary costs for demurrage for Chinese purchasers. ${ }^{(70)}$ QIPs are granted for limited periods (extended from three months to six months), locking purchasers into a tight window in which to purchase, transport, and discharge cargoes. ${ }^{(71)}$ It may be questioned whether these QIP requirements are the least trade-restrictive means to achieve China's health objectives.

Another example is the "zero-tolerance" standard imposed by China on food pathogens such as Salmonella and Listeria, which has led to several foreign meat and poultry facilities being "delisted" (i.e., removed from the list of facilities authorised to export to China). This measure can be seen as unduly trade restrictive, as zero tolerance is an unattainable standard in the case of certain unavoidable pathogens present at levels that do not pose risks to consumers. ${ }^{72}$ )

The requirement that a food safety requirement be no more trade restrictive than necessary brings much-needed discipline to regulatory measures that overreach their objectives. As such, it may serve to improve China's regulatory efforts by ensuring that they are rationally designed and well suited to achieving their food safety objectives.

\section{Transparency and adaptation period}

An important and possibly underestimated aspect of the SPS Agreement is its insistence on transparency of SPS measures. The significance of transparency disciplines lies in two main areas.

First, it has what can be called ex ante effects. Exporters of food and agricultural products are affected by regulatory decisions taken in foreign jurisdictions, yet they traditionally have no say in the decision-making process. Foreign regulators take into account national priorities and interests when making decisions on food safety measures. This raises the problem that Robert Keohane has called the "external accountability gap," (73) describing the situation that arises in a globalising world where the impact of a state's actions surpasses its jurisdiction and affects the lives of persons outside it. Imposing ex ante transparency obligations on regulating countries ensures that exporting countries are informed of proposed new or amended food safety measures and that affected foreign traders have the opportunity, through their governments, to raise concerns regarding these proposed measures and to have these comments taken into account in the regulatory process.

The second important aspect of transparency lies in its ex post effects. An important hurdle to exporters of food and agricultural products is the paucity of information available regarding the food safety requirements they must comply with in their export markets. These requirements are often complex and subject to change, as a result of which exporters have no certainty that their products will have access to the market of the destination country. Obtaining information on food safety requirements is often a costly and burdensome process for exporters. Transparency obligations requiring publication of adopted food safety regulations greatly reduce the cost and difficulty of obtaining information on trading partners' requirements.

The ex post effect of transparency is not only important for traders, but is also essential in enabling WTO Members to exercise their rights and police

65. The Standards and Trade Development Facility is a joint initiative of the World Bank, WTO, FAO, WHO, and OIE to promote capacity building and technical cooperation on sanitary and phytosanitary (SPS) issues. It aims to increase coordination in the provision of SPS-related assistance, and mobilise resources to help developing countries enhance their SPS capacity.

66. World Trade Organization, SPS Agreement, op. cit., Annex A.

67. Ibid., Article 5.6 .

68. Committee on Sanitary and Phytosanitary Measures, Transitional Review Mechanism Pursuant to Paragraph 18 of the Protocol on The Accession of the People's Republic of China, Questions from the European Communities to China concerning Sanitary and Phytosanitary Measures, G/SPS/GEN/968, 20 October 2009, para 14.

69. United States Trade Representative, 2010 Report to Congress on China's WTO Compliance, op. cit., p. 81.

70. Emerging Markets Group \& Development Solutions, Study on the Future Opportunities and Challenges of EU-China Trade and Investment Relations, Study 6: Agriculture, Study Commissioned by the European Commission, February 2007, p. 21, http://trade.ec.europa.eu/doclib/docs/2007/february/tradoc_133308.pdf (consulted on 22 February 2012).

71. United States Trade Representative, 2010 Report to Congress on China's WTO Compliance, op. cit., p. 82.

72. United States Trade Representative, 2010 Report to Congress on China's WTO Compliance, op. cit., p. 79; see also Emerging Markets Group \& Development Solutions, Study on the Future Opportunities and Challenges of EU-China Trade and Investment Relations, Study 6: Agriculture, Study Commissioned by the European Commission, op.cit., p. 20.

73. Robert Keohane, "Global Governance and Democratic Accountability," in David Held and Mathias Koenig-Archibugi (eds.), Taming Globalization: Frontiers of Governance, Hoboken (NJ), WileyBlackwell, 2003, p. 141. 
the implementation of the obligations of the SPS Agreement. ${ }^{(74)}$ Lack of information regarding the existence, content, and scientific basis of food safety regulations makes it difficult for members to determine whether the SPS Agreement provides them with legal grounds to challenge measures that serve as sanitary barriers to trade. Transparency also makes it possible for traders to be well informed as to the effect of SPS measures on their exports and to lobby their governments to take action in this regard. Consequently, members can try to resolve their trade concerns in bilateral discussions with the relevant member, ${ }^{(75)}$ in multilateral discussions at SPS Committee meetings, or in formal dispute-settlement proceedings. For these reasons, the SPS Agreement has rules in place to promote transparency in SPS regulation. ${ }^{(76)}$ These rules require not only that adopted SPS regulations be published promptly and provide a reasonable period between publication and entry into force of the regulation for members to adapt to the new requirements, but also that early notice be given of draft SPS legislation, along with a comment period for other members. Copies of the draft legislation must be provided upon request.

These transparency requirements have been very weakly implemented by China to date. ${ }^{(77)}$ For example, the EU has complained that China has not fulfilled its obligation as regards transparency towards trading partners while developing its SPS legislation. ${ }^{(78)}$ Although China has issued a vast number of notifications of draft sanitary and phytosanitary legislation, with 619 regular and emergency measures notified since its accession in 2001, (79) the EU notes that in practice, access to China's SPS legislation and opportunities to comment on the draft legislation remain limited. This is because China has not made its regulations available in one or more WTO languages, despite its accession commitment to do so. ${ }^{(80)}$ In addition, according to the EU it is not always clear whether the comments given by trading partners are taken into account by China before it finalises its food safety regulations. Finally, the EU has pointed out that China does not always comply with its the obligation to allow a reasonable adaptation period between the publication of an SPS regulation and its entry into force. ${ }^{(81)}$

One specific example of the failure to comply with the transparency obligations of the SPS Agreement is the following. On 1 June 2009, China's new Food Safety Law and the Regulation on the Implementation of the Food Safety Law entered into force. However, China gave no notice of either this new legislation or its implementing regulation before implementation. Further, other members were given no "reasonable adaptation period" as required by the SPS Agreement between the publication of a sanitary and phytosanitary regulation and its entry into force. ${ }^{\left({ }^{82}\right)}$ Such lack of transparency acts as a formidable barrier to market access and is subject to challenge under the rules of the SPS Agreement.

Greater transparency in China's food safety regulation could not only improve the prospects for foreign exporters, but could also contribute to good governance, thereby building the trust of consumers in the safety of food products. Such confidence-building is essential in the wake of the food safety scandals that have shaken citizens' faith in government oversight of the food industry.

\section{Undue delays}

In order to ensure compliance with their food safety requirements, members usually have control, inspection, and approval procedures in place. If these procedures are complex, lengthy, or costly, they may effectively re- strict market access, especially in the case of perishable products. The SPS Agreement therefore contains detailed rules on control inspection and approval procedures, which broadly aim to ensure that procedures are not more lengthy and burdensome than is reasonable and necessary and that they do not discriminate against imports. ${ }^{(83)}$ Whether a procedural delay is "unreasonable" depends, according to the Panel in the EC-Biotech Products case, ${ }^{(84)}$ not on the length of the delay but on whether there is a legitimate reason or justification for it. Members imposing approval procedures must be allowed to take the time reasonably needed to ensure with adequate confidence that their food safety requirements are complied with.

The EU has noted that the slow progress of negotiations over sanitary protocols and the slow progress for inspections impose considerable market access restrictions for EU exports to China, especially for meat, fruit, and vegetables. ${ }^{\left({ }^{85}\right)}$ In particular, concerns have been raised that China's approach to audit and inspection, which deviates from the standard laid down by the Codex Alimentarius Commission, results in unjustified delays. Lacking adequate justification, such procedural delays may be challenged under the rules of the SPS Agreement. ${ }^{(86)}$

\section{Conclusion}

The current proliferation of food safety measures in China in response to the growing demands of its consumers and trading partners on the one hand, and the great advancements in trade liberalisation brought about by China's accession to the WTO on the other, mean that the interaction between the

74. Scott refers to this as the "all-important accountability function" of transparency, which operates to enable other Members to evaluate and contest proposed SPS regulation. Joanne Scott, "The WTO Agreement on Sanitary and Phytosanitary Measures: A Commentary," Oxford Commentaries on the GATT/WTO Agreements, Oxford, Oxford University Press, 2007, pp. 192-193.

75. Wolfe notes that the WTO Secretariat "knows that the real reason many experts attend [SPS] Committee meetings is to hold private unrecorded bilateral meetings with each other." Robert Wolfe, "See You in Geneva? Legal (Mis)Representations of the Trading System," European Journal of International Relations, vol. 11, no. 3, p. 353.

76. World Trade Organization, SPS Agreement, op. cit., Article 7, Annex B and Article 5.8.

77. For an analysis of the underlying reasons for China's poor implementation of the SPS Agreement's transparency obligations, including cultural norms, local practices, and regulatory infrastructure, see Ljiljana Biukovic, "Selective adaptation of WTO transparency norms and local practices in China and Japan," in Debra P. Steger (ed.), Redesigning the World Trade Organization for the Twenty-First Century, Wilfrid Laurier Press, 2010, pp. 193-218.

78. Committee on Sanitary and Phytosanitary Measures, Transitional Review Mechanism Pursuant to Paragraph 18 of the Protocol on the Accession of the People's Republic of China ("China"), Questions from the European Communities to China concerning Sanitary and Phytosanitary Measures, G/SPS/W/262, 6 October 2011, para 4.

79. See Committee on Sanitary and Phytosanitary Measures, Overview regarding the Level of Implementation of the Transparency Provisions of the SPS Agreement, Note by the Secretariat, G/SPS/GEN/804/Rev.4, 13 October 2011.

80. See the Report of the Working Party on the Accession of the People's Republic of China, para 334.

81. Committee on Sanitary and Phytosanitary Measures, Transitional Review Mechanism Pursuant to Paragraph 18 of the Protocol on the Accession of the People's Republic of China ("China"), Questions from the European Communities to China concerning Sanitary and Phytosanitary Measures, G/SPS/W/262, 6 October 2011, para 6.

82. Committee on Sanitary and Phytosanitary Measures, Transitional Review Mechanism Pursuant to Paragraph 18 of the Protocol on the Accession of the People's Republic of China, Questions from the European Communities to China concerning Sanitary and Phytosanitary Measures, G/SPS/GEN/968, 20 October 2009, para 13

83. World Trade Organization, SPS Agreement, op. cit., Article 8 and Annex C.

84. Panel Reports, EC-Approval and Marketing of Biotech Products, paras 7.1496-1498 and 7.15111530.

85. Committee on Sanitary and Phytosanitary Measures, Transitional Review Mechanism Pursuant to Paragraph 18 of the Protocol on the Accession of the People's Republic of China ("China"), Questions from the European Communities to China concerning Sanitary and Phytosanitary Measures, G/SPS/W/262, 6 October 2011, para 16.

86. Ibid., para 17. 
two policy areas of trade and health has assumed critical importance for China. The impetus thus generated for concerted efforts by China to reform its food safety regime can only be welcomed. However, these efforts should take into account the framework of disciplines on sanitary and phytosanitary measures contained in the WTO's SPS Agreement. This contribution sketched out the impact of this framework on China's regulatory autonomy.

From the foregoing analysis it appears that the SPS Agreement should not be seen as a hurdle to China's ability to improve its food safety regulatory regime. Instead, the Agreement operates to achieve a balance between the trade and health objectives of all WTO Members. As such, it sets the limits within which China may exercise its sovereign right to take measures to protect consumers in its territory from food safety risks and to achieve the level of health protection it deems appropriate.

These limits are there to promote rationality in SPS regulation and to prevent restrictions that are based on unfounded fears or are a response to protectionist pressures from the domestic industry. They can be seen as laying down a "best practices" model for food safety regulation. WTO Members may rely on the disciplines of the SPS Agreement to challenge food safety requirements faced by their exporters that lead to trade restrictions, either through raising their concerns bilaterally or in the multilateral forum of the SPS Committee, or as a last resort by bringing a dispute under the WTO dispute settlement mechanism. They may also use the trade policy review mechanism (and until recently the transitional review mechanism for China) to highlight their concerns with reference to the disciplines of the SPS Agreement.

To date, China's food safety measures have been the subject of discussions in all these fora except for the dispute settlement mechanism. WTO Members have worked to find constructive solutions to the problems raised rather than seeking adjudicative solutions. The EU, for example, has noted the significant efforts made by China to reform its sanitary and phytosanitary regime in line with its obligations under the SPS Agreement and has recognised that with the increase in trade this work is growing. ${ }^{(87)}$ Technical exchanges and training have been provided by China's trading partners to disseminate best practices in food safety. ${ }^{(88)}$

China has a formidable task before it to bring its food safety regime into conformance with the requirements of the SPS Agreement. It must give effect to its health objectives in a manner that respects the disciplines laid down in this Agreement, a sometimes costly and administratively burdensome task. However, by doing so it would not only create gains for exporters, but most importantly it would produce real benefits for its consumers in the form of a rigorous and science-based food safety system. Further, it should not be forgotten that at the same time China can, and does, use the same Agreement to challenge the trade restrictions imposed by its trading partners in the form of SPS requirements. ${ }^{(89)}$ It is through its careful balance between trade and health concerns that the SPS Agreement serves the interests of all WTO Members.
87. Ibid., para 3.

88. For example, several government agencies dealing with food safety in the US have engaged in collaboration with Chinese regulators and producers to improve food safety practices. See F. Gale \& J.C. Buzby, "Imports from China and food safety issues," op. cit.

89. In 2009, China initiated a WTO dispute settlement proceeding against the United States in respect of restrictions on its poultry exports. The measure at issue was Section 727 of the US Omnibus Appropriations Act of 2009, which in effect prohibited the implementation of any measures that would allow Chinese poultry to be imported into the US by denying the use of any funding by USDA for this purpose. The WTO Panel found the US measure in violation of the SPS Agreement, and recommended its withdrawal. The US did not appeal this decision. See Panel Report, US Poultry, WT/DS392/R, adopted 25 October 2010. 